UDK 577.1 : 61

ISSN 1452-8258

J Med Biochem 41: 40-46, 2022

\title{
DO THE ETIOLOGY OF HYPONATREMIA AND SERUM SODIUM LEVELS AFFECT THE LENGTH OF HOSPITAL STAY IN GERIATRIC PATIENTS WITH HYPONATREMIA?
}

\section{DA LI ETIOLOGIJA HIPONATREMIJE I NIVOI SERUMSKOG NATRIJUMA UTIČU NA DUŽINU BORAVKA U BOLNICI KOD GERIJATRIJSKIH BOLESNIKA SA HIPONATREMIJOM?}

\author{
Salih Baser ${ }^{1}$, Nuray Yılmaz Cakmak², Emin Gemcioglu² \\ ${ }^{1}$ Yıldırım Beyazıt University, Faculty of Medicine, Ankara City Hospital, Department of Internal Medicine, \\ Ankara, Turkey \\ ${ }^{2}$ Ankara City Hospital, Department of Internal Medicine, Ankara, Turkey
}

\begin{abstract}
Summary
Background: Hyponatremia can lead to a prolonged hospital stay and increased morbidity and mortality rates in geriatric patients. This study aimed to evaluate the effects of hyponatremia etiology and serum sodium $(\mathrm{Na})$ levels on hospitalisation time in geriatric patients hospitalised due to hyponatremia.

Methods: The demographic characteristics, laboratory data, etiology of hyponatremia, and length of hospital stay were retrospectively recorded for 132 patients over 65 years of age who were hospitalised for hyponatremia.

Results: Of the 132 patients, 90 were female (68.2\%), and 42 were male (31.8\%). The serum $\mathrm{Na}$ levels of $66(50 \%)$ patients were $<120 \mathrm{mmol} / \mathrm{L}$, those of $64(48.5 \%)$ patients were $120-129 \mathrm{mmol} / \mathrm{L}$, and those of two $(1.5 \%)$ patients were $>130 \mathrm{mmol} / \mathrm{L}$. One hundred nine $(82.6 \%)$ patients had hypoosmolar hyponatremia, $14(10.6 \%)$ patients had isoosmolar hyponatremia, and nine (6.8\%) patients had hyperosmolar hyponatremia. Also, $19.7 \%$ of the patients were hypovolemic, $37.9 \%$ were euvolemic, and $42.4 \%$ were hypervolemic. Hyponatremia etiology was congestive heart failure in $38(28.8 \%)$ patients, syndrome of inappropriate antidiuretic hormone in $29(22.0 \%)$ patients, gastrointestinal fluid loss in $24(18.2 \%)$ patients, renal pathologies in $20(15.2 \%)$ patients, the presence of drugs in $20(15.2 \%)$ patients, and hypocortisolemia in one $(0.8 \%)$ patient. The mean length of hospital stay for the patients was five (1-60) days. There was no statistically significant difference between the lengths of hospital stay
\end{abstract}

\section{Kratak sadržaj}

Uvod: Hiponatremija može dovesti do produženog boravka u bolnici i povećane stope morbiditeta i mortaliteta kod gerijatrijskih pacijenata. Cilj ove studije bio je da se procene efekti etiologije hiponatremije i nivoa natrijuma $(\mathrm{Na}) \mathrm{u}$ serumu na vreme hospitalizacije kod gerijatrijskih pacijenata hospitalizovanih zbog hiponatremije.

Metode: Retrospektivno su zabeležene demografske karakteristike, laboratorijski podaci, etiologija hiponatremije i dužina boravka u bolnici za 132 pacijenta starijih od 65 godina koji su hospitalizovani zbog hiponatremije.

Rezultati: Od 132 pacijenta, 90 su bile žene (68,2\%), a 42 muškarci (31,8\%). Nivoi Na u serumu 66 (50\%) pacijenata su bili $<120 \mathrm{mmol} / \mathrm{L}$, kod $64(48,5 \%)$ pacijenata su bili 120-129 mmol/L, a kod dvoje (1,5\%) pacijenta > 130 $\mathrm{mmol} / \mathrm{L}$. Sto devet $(82,6 \%)$ pacijenata je imalo hipoosmolarnu hiponatremiju, $14(10,6 \%)$ bolesnika je imalo izoosmolarnu hiponatremiju, a devetoro $(6,8 \%)$ pacijenata je imalo hiperosmolarnu hiponatremiju. Takođe, 19,7\% pacijenata bilo je hipovolemično, 37,9\% euvolemično, a 42,4\% hipervolemično. Kod 38 (28,8\%) pacijenata etiologija hiponatremije je bila kongestivna srčana insuficijencija, kod $29(22,0 \%)$ pacijenata sindrom neodgovarajućeg antidiuretskog hormona, gubitak gastrointestinalne tečnosti kod $24(18,2 \%)$ pacijenata, bubrežne patologije kod 20 $(15,2 \%)$ pacijenata, prisustvo lekova kod $20(15,2 \%)$ pacijenata, a kod jednog $(0,8 \%)$ pacijenta hipokortizolemija. Prosečna dužina boravka u bolnici za pacijente bila je pet (1-60) dana. Nije bilo statistički značajne razlike između dužine boravka u bolnici na osnovu etiologije hiponatremije

\footnotetext{
Address for correspondence:

Emin Gemcıoglu, MD

Ankara City Hospital, Department of Internal Medicine

Ankara 06100, Turkey

Phone: +90-505-9369141

Fax: +90-312-3100194

e-mail: egemcioglu@gmail.com
} 
based on hyponatremia etiology and serum $\mathrm{Na}$ levels $(p=0.861$ and $p=0.076)$. It was observed that the lengths of stay for patients who developed hyponatremia during their hospitalisation in various clinics were longer than those for patients who presented to the emergency department $(p<0.001)$.

Conclusions: In this study, it was determined that the length of hospital stay did not change with the etiology of hyponatremia and serum $\mathrm{Na}$ level at the time of admission, but patients who developed hyponatremia during their hospitalisation had longer hospitalisation times.

Keywords: hyponatremia, geriatrics, length of stay

\section{Introduction}

Hyponatremia is the most common electrolyte abnormality observed in clinical practice. It can be seen in about $30 \%$ of hospitalised patients and can lead to a wide range of clinical symptoms, from asymptomatic to severe and even life-threatening (1, 2).

In order to determine the diagnosis and treatment in patients presenting with hyponatremia, grouping is performed according to patients' serum osmolality and volume status. Serum osmolality is grouped as hypoosmolar at $<280 \mathrm{mmol} / \mathrm{kg}$, isoosmolar at $280-295 \mathrm{mmol} / \mathrm{kg}$, and hyperosmolar at $>295 \mathrm{mmol} / \mathrm{kg}$, with a further categorisation of hypovolemic, euvolemic, or hypervolemic hyponatremia according to volume status. Symptoms depend on the severity and duration of the hyponatremia. Acute hyponatremia is defined by the onset of symptoms within $48 \mathrm{~h}$. Patients with acute hyponatremia develop neurologic symptoms caused by cerebral edema due to water movement into the brain. These may include seizures, impaired mental status, or coma and death. Hyponatremia developing over longer than $48 \mathrm{~h}$ is considered chronic hyponatremia. Treatment depends on the acute or chronic onset, the patient's volume status, and the severity and nature of the symptoms.

Age is a strong independent risk factor for hyponatremia, and older patients constitute a highrisk group for its occurrence (2-5). Symptoms such as nausea, vomiting, headache, stupor, coma, and seizures are associated with acute hyponatremia and fatigue, cognitive impairment, and gait defects are associated with chronic hyponatremia; also, falls, poor bone quality (e.g., osteoporosis), and negative effects of fractures are more frequent and severe in geriatric patients (6-10). Hyponatremia also prolongs the hospitalisation time remarkably and increases the cost of medical care substantially (11). It is unknown whether there is a relationship between the etiology of hyponatremia or initial serum sodium $(\mathrm{Na})$ levels and the length of hospital stay. This study intended to evaluate the clinical features, hyponatremia etiologies, and hospitalisation durations of hyponatremic patients over 65 years of age and determine whether i nivoa $\mathrm{Na}$ u serumu ( $p=0,861$ i $p=0,076)$. Uočeno je da su dužine boravka kod pacijenata koji su razvili hiponatremiju tokom hospitalizacije u raznim klinikama bile duže nego kod pacijenata koji su došli na odeljenje hitne pomoći $(p<0,001)$.

Zaključak: U ovoj studiji je utvrđeno da se dužina boravka $u$ bolnici nije menjala sa etiologijom hiponatremije i nivoa $\mathrm{Na}$ u serumu u trenutku prijema, ali su pacijenti koji su razvili hiponatremiju tokom hospitalizacije imali duže vreme hospitalizacije.

Ključne reči: hiponatremija, gerijatrija, dužina boravka

there is a relationship between hyponatremia etiology and the length of hospital stay.

\section{Materials and Methods}

\section{Study Population}

In this study, 132 patients aged 65 years who were hospitalised in our clinic due to hyponatremia were evaluated retrospectively. Patients with complete data were included in the study. Patients aged $<65$ years and those with hyperglycemia, hyperlipidemia, or paraproteinemia that could cause pseudohyponatremia were excluded from the study. The approval of the local ethics committee was obtained (18.09.2019/94).

The demographic characteristics of the patients (age, gender) and their places of presentation (emergency room, other clinics), presenting complaints (nausea, vomiting, confusion, seizure, fever, dyspnea, edema, general condition disorder, fatigue, anorexia), physical examination findings, volume statuses (hypovolemic, euvolemic, hypervolemic), hyponatremia etiologies, treatments (hypertonic saline, isotonic saline, water restriction, diuretics, ultrafiltration), and laboratory data (glucose, urea, creatinine, serum osmolality, $\mathrm{Na}$, potassium (K), urine $\mathrm{Na}$, urine osmolality, hemoglobin, thyrotropin (TSH), and serum cortisol levels) were recorded. The normal serum $\mathrm{Na}$ range is $135-145 \mathrm{mmol} / \mathrm{L}$, serum osmolality is 275 $293 \mathrm{mmol} / \mathrm{kg}$ serum water, and urine osmolality is $500-850 \mathrm{mmol} / \mathrm{kg}$ water. Hyponatremia is defined as an $\mathrm{Na}$ of $<135 \mathrm{mmol} / \mathrm{L}$, and severe hyponatremia is defined as serum $\mathrm{Na}$ of $<120 \mathrm{mmol} / \mathrm{L}$.

\section{Statistical Analysis}

The IBM SPSS 21.0 statistical software package for Windows was used for the statistical analysis of the data. For all data, the normality assumption was evaluated via the Shapiro-Wilk test. Numerical data are indicated by median (minimum-maximum), and categorical data are indicated by numbers (percentage). The Mann-Whitney $U$ test was used to compare numerical data between two groups, and the Kruskal- 
Wallis test was used to compare more than two groups. Values of $p<0.05$ were considered statistically significant.

\section{Results}

Of the 132 patients, 90 were female (68.2\%), 42 were male $(31.8 \%)$, and the mean age was $74.97 \pm 7.14$ years. Severe hyponatremia ( $\mathrm{Na}$ of $<120 \mathrm{mmol} / \mathrm{L})$ was detected in $66(50 \%)$ patients.

While 97 (73.5\%) patients presented to the emergency department with complaints related to hyponatremia, $35(26.5 \%)$ patients were found to have developed hyponatremia during their hospitalisation in various clinics. Dyspnea and edema were observed in 28 (21.2\%) patients, nausea/vomiting in $26(19.7 \%)$ patients, confusion in $26(19.7 \%)$ patients, fatigue and anorexia in 15 (11.4\%) patients, seizures in eight (6.1\%) patients, fever in eight (6.1\%) patients, and general condition disorder in five (3.8\%) patients, whereas 16 (12.1\%) patients were asymptomatic. The median systolic blood pressure of the patients was $120(68-250) \mathrm{mmHg}$, and the mean diastolic blood pressure was $70(39-130) \mathrm{mmHg}$. The physical examination findings of the patients at the time of admission are presented in Table $I$. Hypovolemic hyponatremia was detected in 26 $(19.7 \%)$ patients, euvolemic hyponatremia in 50 (37.9\%) patients, and hypervolemic hyponatremia in 56 (42.4\%) patients.

Serum Na level was 119.50 (99-131) mmol/L at the time of admission, $125(105-139) \mathrm{mmol} / \mathrm{L}$ at the 24th hour of treatment, and 128.50 (108-144) $\mathrm{mmol} / \mathrm{L}$ at the 48th hour of treatment $(\mathrm{p}<0.001)$. The serum $\mathrm{Na}$ levels of $66(50 \%)$ patients were $<120$ $\mathrm{mmol} / \mathrm{L}$, those of 64 (48.5\%) patients were 120-129 $\mathrm{mmol} / \mathrm{L}$, and those of two (1.5\%) patients were $>130 \mathrm{mmol} / \mathrm{L}$. One hundred nine (82.6\%) patients had hypoosmolar hyponatremia, $14(10.6 \%)$ patients had isoosmolar hyponatremia, and nine (6.8\%) patients had hyperosmolar hyponatremia (Table II).

The etiology of hyponatremia was congestive heart failure in 38 (28.8\%) patients, syndrome of inappropriate antidiuretic hormone $(A D H)$ secretion (SIADH) in $29(22.0 \%)$ patients, gastrointestinal fluid loss in $24(18.2 \%)$ patients, renal pathologies in 20 $(15.2 \%)$ patients, the presence of drugs in 20 (15.2\%) patients, and hypocortisolemia in one (0.8\%) patient. In $51.7 \%$ of patients with SIADH, the cause was an infection, with the most common (66.7\%) reason being pneumonia.

Sixty-eight (51.5\%) patients were treated with hypertonic saline, 20 (15.2\%) with isotonic saline, 24 $(18.2 \%)$ with water restriction and diuretics, and 20 $(15.2 \%)$ with only water restriction. It was observed that seven (5.3\%) patients required ultrafiltration.

The mean length of hospital stay for the patients was $5(1-60)$ days. There was no statistically
Table I Demographic features, complaints, and physical examination findings of the patients.

\begin{tabular}{|l|c|}
\hline & $\mathrm{n}(\%)$ \\
\hline Gender & $90(68.2)$ \\
\hline Female & $42(31.8)$ \\
\hline Male & \\
\hline Place of application & $97(73.5)$ \\
\hline Emergency department & $35(26.5)$ \\
\hline Different clinics & \\
\hline Complaints & $28(21.2)$ \\
\hline Dyspnea/edema & $26(19.7)$ \\
\hline Nausea/vomiting & $26(19.7)$ \\
\hline Confusion & $16(12.1)$ \\
\hline Asymptomatic & $15(11.4)$ \\
\hline Fatigue/anorexia & $8(6.1)$ \\
\hline Seizures & $8(6.1)$ \\
\hline Fever & $5(3.8)$ \\
\hline General condition disorder & \\
\hline Physical examination & $56(37.8)$ \\
\hline Rales in the lung & \\
\hline Present & $52(36.2)$ \\
\hline Absent & $90(68.2)$ \\
\hline Ascites & \\
\hline Present & \\
\hline Absent & \\
\hline Pretibial edema & \\
\hline Present & $(71.7)$ \\
\hline Absent & \\
\hline Volume & \\
\hline Hypovolemic & \\
\hline Euvolemic & \\
\hline Hypervolemic & \\
\hline & \\
\hline
\end{tabular}

significant difference between the lengths of hospital stay in terms of hyponatremia etiologies $(p=0.861)$. In addition, serum $\mathrm{Na}$ levels at the time of presentation did not show a statistically significant difference in terms of hyponatremia etiologies $(p=0.065)$. It was observed that the lengths of hospital stay and serum $\mathrm{Na}$ levels at the time of presentation were similar in female and male patients $(p=0.440$ and $p=0.230)$. 
Table II Laboratory values of the patients.

\begin{tabular}{|c|c|}
\hline & Median (min-max) \\
\hline Glucose (mmol/L) & $5.44(3.77-6.72)$ \\
\hline Urea nitrogen (mmol/L) & $7.32(0.51-36.03)$ \\
\hline Creatinine $(\mu \mathrm{mol} / \mathrm{L})$ & 79.56 (13.26-739.9) \\
\hline Potassium (mmol/L) & $4.40(2.30-6.70)$ \\
\hline TSH (mIU/L) & $1.1(0.92-5.2)$ \\
\hline Serum cortisol (nmol/L) & $317.2(110.3-717.2)$ \\
\hline Hemoglobin (g/L) & $112(62-179)$ \\
\hline $\begin{array}{l}\text { Serum Na level at the time of } \\
\text { admission }(\mathrm{mmol} / \mathrm{L})\end{array}$ & 119.50 (99-131) \\
\hline $\begin{array}{l}\text { Serum } \mathrm{Na} \text { level at the } 24 \text { th hour } \\
\text { of treatment }(\mathrm{mmol} / \mathrm{L})\end{array}$ & 125 (105-139) \\
\hline $\begin{array}{l}\text { Serum } \mathrm{Na} \text { level at the 48th hour } \\
\text { of treatment }(\mathrm{mmol} / \mathrm{L})\end{array}$ & 128.50 (108-144) \\
\hline Serum osmolality $(\mathrm{mmol} / \mathrm{kg})$ & 259 (212-309) \\
\hline Urine osmolality $(\mathrm{mmol} / \mathrm{kg})$ & $224(36-782)$ \\
\hline Urine $\mathrm{Na}(\mathrm{mmol} / \mathrm{L})$ & $45.5(4-321)$ \\
\hline $\mathrm{Na}$ groups & n (\%) \\
\hline $\begin{array}{l}<120 \mathrm{mmol} / \mathrm{L} \\
120-129 \mathrm{mmol} / \mathrm{L} \\
130-135 \mathrm{mmol} / \mathrm{L}\end{array}$ & $\begin{array}{c}66(50) \\
64(48.5) \\
2(1.5)\end{array}$ \\
\hline Osmolality groups & n (\%) \\
\hline $\begin{array}{l}\text { Hypoosmolar } \\
\text { Isoosmolar } \\
\text { Hyperosmolar }\end{array}$ & $\begin{array}{c}109(82.6) \\
14(10.6) \\
9(6.8)\end{array}$ \\
\hline
\end{tabular}

TSH: Thyrotropin, Na: sodium

In addition, there was no statistically significant difference between the duration of hospital stay in patients with serum $\mathrm{Na}$ levels of $<120 \mathrm{mmol} / \mathrm{L}$ and 120-129 $\mathrm{mmol} / \mathrm{L}$ at the time of admission $(p=0.076)$. It was observed that the lengths of hospital stay for patients who developed hyponatremia during their hospitalisation in various clinics was longer than those of patients who presented to the emergency department $(p<0.001)$, but serum $\mathrm{Na}$ levels were higher in patients who developed hyponatremia during hospitalisation $(p<0.001)$ (Table III).
Table III Duration of hospitalisation and sodium levels at the time of patients' admission according to gender, etiology, place of application, and patients' duration of hospitalisation according to sodium groups.

\begin{tabular}{|c|c|c|c|c|}
\hline & $\begin{array}{l}\text { Duration } \\
\text { of hospi- } \\
\text { talisation }\end{array}$ & $\mathrm{p}$ & $\begin{array}{c}\text { Na levels } \\
\text { at the time } \\
\text { of admission }\end{array}$ & $\mathrm{p}$ \\
\hline \multicolumn{5}{|l|}{ Gender } \\
\hline Female & $4(1-60)$ & \multirow{2}{*}{0.440} & $\begin{array}{c}119 \\
(101-131)\end{array}$ & \multirow{2}{*}{0.230} \\
\hline Male & $7(1-43)$ & & $\begin{array}{c}121 \\
(99-129)\end{array}$ & \\
\hline \multicolumn{5}{|l|}{ Etiology } \\
\hline $\begin{array}{l}\text { Congestive } \\
\text { heart failure }\end{array}$ & $4(1-30)$ & \multirow{5}{*}{0.861} & $\begin{array}{c}119 \\
(99-128)\end{array}$ & \multirow{5}{*}{0.065} \\
\hline SIADH & $6(1-59)$ & & $\begin{array}{c}121 \\
(109-129)\end{array}$ & \\
\hline $\begin{array}{l}\text { Gastrointestinal } \\
\text { fluid loss }\end{array}$ & $4(1-36)$ & & $\begin{array}{c}119 \\
(101-126)\end{array}$ & \\
\hline $\begin{array}{l}\text { Renal } \\
\text { pathologies }\end{array}$ & $7(1-60)$ & & $\begin{array}{c}122.5 \\
(105-129)\end{array}$ & \\
\hline Drugs & $4(1-43)$ & & $\begin{array}{c}120.5 \\
(108-131)\end{array}$ & \\
\hline \multicolumn{5}{|c|}{ Place of application } \\
\hline $\begin{array}{l}\text { Emergency } \\
\text { department }\end{array}$ & $3(1-59)$ & \multirow{2}{*}{$<0.001$} & $\begin{array}{c}118 \\
(99-130)\end{array}$ & \multirow{2}{*}{$<0.001$} \\
\hline Different clinics & $10(2-60)$ & & $\begin{array}{c}124 \\
(111-131)\end{array}$ & \\
\hline \multicolumn{5}{|l|}{$\mathrm{Na}$ groups } \\
\hline$<120 \mathrm{mmol} / \mathrm{L}$ & $4(1-59)$ & \multirow{2}{*}{0.076} & \multirow{2}{*}{ - } & \multirow[b]{2}{*}{ - } \\
\hline $120-129$ & $6(1-60)$ & & & \\
\hline
\end{tabular}

$\mathrm{Na}$ : Sodium, SIADH: syndrome of inappropriate antidiuretic hormone secretion

\section{Discussion}

Hyponatremia is the most common electrolyte disorder in hospitalised patients and society. Hyponatremia prevalence in society is $~ 8 \%$, and this prevalence increases significantly with age $(3,4)$. Hyponatremia is reported to be associated with an increased risk of mortality and poor prognosis in older individuals $(3,12)$.

The higher rate of hyponatremia in the elderly is related to the deterioration of the water excretion capacity associated with aging and the more frequent exposure of this group to drugs and diseases associated with hyponatremia $(2,13)$. The decrease in the glomerular filtration rate due to aging causes impaired water excretion capacity. In addition, the decrease in intrarenal prostaglandin production seen at older ages may cause impaired water excretion 
capacity (14). Another factor contributing to hyponatremia in this group is the fact that the age-related decrease in total body water percentage causes further fluctuations in serum $\mathrm{Na}$ concentration. Higher sensitivity to osmotic stimuli can be seen in the geriatric population $(15,16)$. Elderly individuals frequently use drugs known to cause hyponatremia (such as thiazide diuretics, selective serotonin reuptake inhibitors, and nonsteroidal anti-inflammatory drugs), and they often suffer from diseases that may be associated with hyponatremia (for example, diabetes mellitus, infections, heart failure, liver diseases, malignancies, and endocrinopathies) $(17,18)$. Many elderly patients with hypertension or heart failure maintain a low-salt diet, which can cause a low serum $\mathrm{Na}$ concentration. In this population, a decrease in protein intake due to overlapping diseases may play a role in the development of hyponatremia by impairing water excretion $(19,20)$.

Diuretics and SIADH are among the most common causes of hyponatremia in the elderly $(20,21)$. In one prospective study that included only elderly hospitalised patients, the most common causes of hyponatremia were SIADH and diuretics. In the same study, the two most common causes of SIADH were lower respiratory tract infection and stroke (22). In the study of Chatterjee et al. (23), gastrointestinal fluid loss, cerebrovascular accident, and pulmonary sepsis were found to be the most frequent causes of hyponatremia. In the work of Babaliche et al. (24), SIADH was also the most common cause of hyponatremia in $46 \%$ of patients, followed by renal pathologies in 13\%, gastrointestinal compromise in $11 \%$, cardiac causes in $10 \%$, cirrhosis in $10 \%$, and drugs in 10\%. In addition, Ishikawa et al. (25) reported that $40 \%$ of patients presenting with hyponatremia aged 65 and above had hypothalamic-pituitaryadrenal dysfunction. Although congestive heart failure was reported in other studies as a less common cause of hyponatremia than diuretics and $\mathrm{SIADH}$, the most common cause of hyponatremia in our study was congestive heart failure, the second most common cause was SIADH $(23,24)$. Contrary to the study of Ishikawa et al. (25), hyponatremia due to hypopituitarism was very rare in our study group. This may be because patients with hypopituitarism are asymptomatic for long periods, and their need for hospitalisation is less than those of other patients. Because only hospitalised patients were included in our study, the rate of hypopituitarism may be lower than expected.

The importance of early recognition of hyponatremia and prompt intervention is critical (26). In a large multicenter trial with 151,486 patients, it was shown that all types and grades of dysnatremias were related to increased risk-adjusted and raw hospital mortality rates. The odds ratios for mild, moderate, and severe hyponatremia were 1.32,1.89, and 1.81, respectively (27). Moreover, in addition to mortality, hyponatremia prolongs the hospitalisation time remarkably and increases medical care costs (11). In our study, the length of hospital stay due to hyponatremia was observed to be 5 (1-60) days, and this duration did not change according to the etiology of hyponatremia or the patient's gender or initial serum $\mathrm{Na}$ levels. It was observed that patients who applied to the emergency department had lower $\mathrm{Na}$ levels but shorter hospital stays than patients who developed hyponatremia during their hospitalisation in other clinics.

In their study, including 100 patients with moderate to severe hyponatremia who were monitored in the intensive care unit, Babaliche et al. (24) reported that $59 \%$ of the patients were male and $41 \%$ were female, with a slight dominance of the male gender. In the work of Sood et al. (28), the male-to-female ratio was 1.25:1. In other studies in the literature, male gender dominance is observed in patients with hyponatremia $(23,29)$. Contrary to these studies, in our study, $68.2 \%$ of patients with hyponatremia were female. Since our study consists of randomly recruited patients for a certain period of time, the gender result may be due to this.

In the study of Sood et al. (28), including 106 hyponatremic patients, 90\% were hypoosmolar, 9\% hyperosmolar, and 1\% were isoosmolar, while $40 \%$ were euvolemic, 31\% were hypervolemic, and $29 \%$ were hypovolemic. In the study of Chatterjee et al. (23), $50.74 \%$ of the patients were euvolemic, $26.86 \%$ were hypervolemic, and $22.4 \%$ were hypovolemic, while in the study of Babaliche et al. (24), $50 \%$ were euvolemic, 33\% were hypervolemic, and $17 \%$ were hypovolemic. In our study, $42.4 \%$ of the patients were hypervolemic, $37.9 \%$ were euvolemic, and $19.7 \%$ were hypovolemic while $82.6 \%$ had hypoosmolar hyponatremia, $10.6 \%$ had isoosmolar hyponatremia, and $6.8 \%$ had hyperosmolar hyponatremia.

In their study, Sood et al. (28) reported that $42 \%$ of patients had severe hyponatremia, $48 \%$ had moderate hyponatremia, and $10 \%$ mild hyponatremia. Similarly, in our study, severe hyponatremia was detected in $50 \%$ of the hospitalised geriatric patients. It was observed that $\mathrm{Na}$ levels were $120-129 \mathrm{mmol} / \mathrm{L}$ in $48.5 \%$ and $130-135 \mathrm{mmol} / \mathrm{L}$ in $1.5 \%$ of the patients.

Pillai et al. (30) observed that among intensive care unit admissions, the symptoms attributed to hyponatremia included nausea (69.3\%), malaise (80\%), drowsiness $(61.3 \%)$, confusion $(41.3 \%)$, lethargy $(24 \%)$, frequent falls $(1.3 \%)$, convulsions $(2.7 \%)$, altered sensorium (41.3\%), and delirium (9.3\%). Krishnamurthy and Srinivas (31) reported that the symptoms found in hyponatremia patients were vomiting $(29.6 \%)$, giddiness $(2.4 \%)$, altered sensorium $(8.5 \%)$, headache $(9.2 \%)$, chest pain $(6.4 \%)$, generalized weakness (8.4\%), fever (12.3\%), cough (15.2\%), 
loss of consciousness $(0.7 \%)$, nausea $(22.5 \%)$, loose stools $(5 \%)$, increased fatigability $(10.4 \%)$, breathlessness $(17.8 \%)$, abdominal pain $(8.8 \%)$, difficulty in micturition $(0.9 \%)$, lower limb swelling (3.6\%), and seizures (6.4\%) (31). In our study, dyspnea and edema were observed in $28(21.2 \%)$ patients, nausea/vomiting in 26 (19.7\%) patients, confusion in 26 (19.7\%) patients, fatigue and anorexia in $15(11.4 \%)$ patients, seizures in eight (6.1\%) patients, fever in eight $(6.1 \%)$ patients, and general condition disorder in five $(3.8 \%)$ patients, whereas $16(12.1 \%)$ patients were asymptomatic.

In acute symptomatic hyponatremia, hypertonic saline solution is commonly used to acutely increase serum $\mathrm{Na}$ levels and prevent serious neurological symptoms. Hypovolemic hyponatremia is treated with adequate fluid resuscitation to reduce $A D H$ secretion stimulation. Normal saline is often used to suppress the hypovolemic stimulus that causes $A D H$ release $(32,33)$. In patients with SIADH, careful administration of hypertonic fluids may be required, along with discontinuation of suspicious drugs and reduced water consumption. In these cases, furosemide can also be administered to prevent circulatory overload, especially if elderly patients have concomitant cardiac dysfunction. Furosemide increases free water excretion and leads to higher serum $\mathrm{Na}$. Our study observed that $51.5 \%$ of the patients were treated with

\section{References}

1. Beukhof CM, Hoorn EJ, Lindemans J, Zietse R. Novel risk factors for hospital-acquired hyponatraemia: a matched case-control study. Clin Endocrinol (Oxf) 2007; 66(3): 367-72.

2. Upadhyay A, Jaber BL, Madias NE. Epidemiology of hyponatremia. Semin Nephrol 2009; 29(3): 227-38.

3. Liamis G, Rodenburg EM, Hofman A, Zietse R, Stricker $\mathrm{BH}$, Hoorn EJ. Electrolyte disorders in community subjects: prevalence and risk factors. Am J Med 2013; 126(3): 256-63.

4. Hawkins RC. Age and gender as risk factors for hyponatremia and hypernatremia. Clin Chim Acta 2003; 337(1-2): 169-72.

5. Lindner G, Pfortmüller $C A$, Leichtle $A B$, Fiedler $G M$, Exadaktylos AK. Age-related variety in electrolyte levels and prevalence of dysnatremias and dyskalemias in patients presenting to the emergency department. Gerontology 2014; 60(5): 420-3.

6. Renneboog B, Musch W, Vandemergel X, Manto MU, Decaux G. Mild chronic hyponatremia is associated with falls, unsteadiness, and attention deficits. Am J Med 2006; 119(1): 71.e1-8.

7. Hoorn EJ, Rivadeneira F, van Meurs JB, Ziere G, Stricker $\mathrm{BH}$, Hofman A, et al. Mild hyponatremia as a risk factor for fractures: the Rotterdam Study. J Bone Miner Res 2011; 26(8): 1822-8. hypertonic saline, $15.2 \%$ with isotonic saline, $18.2 \%$ with water restriction and diuretics, and $15.2 \%$ with only water restriction. It was also observed that 5.3\% of the patients required ultrafiltration.

In conclusion, there is an increasing tendency for hyponatremia to occur with increased age, comorbidities, and the use of drugs. In our study, congestive heart failure and SIADH were determined to be the most common causes of hyponatremia in geriatric patients. Nausea, vomiting, and dyspnea were the most common symptoms. It was determined that the length of hospital stay did not change with the etiology of hyponatremia, gender, or serum $\mathrm{Na}$ level at the time of admission. However, patients who developed hyponatremia during their hospitalisation had longer hospitalisation times.

\section{Funding}

The author(s) received no financial support for the research, authorship, and/or publication of this article.

\section{Conflict of interest statement}

All the authors declare that they have no conflict of interest in this work.

8. Renneboog B, Sattar L, Decaux G. Attention and postural balance are much more affected in older than in younger adults with mild or moderate chronic hyponatremia. Eur J Intern Med 2017; 41: e25-e26.

9. Gosch M, Joosten-Gstrein B, Heppner HJ, Lechleitner M. Hyponatremia in geriatric inhospital patients: effects on results of a comprehensive geriatric assessment. Gerontology 2012; 58(5): 430-40.

10. Hoorn EJ, Liamis G, Zietse R, Zillikens MC. Hyponatremia and bone: an emerging relationship. Nat Rev Endocrinol 2011; 8(1): 33-9.

11. Callahan MA, Do HT, Caplan DW, Yoon-Flannery K. Economic impact of hyponatremia in hospitalised patients: a retrospective cohort study. Postgrad Med 2009; 121(2): 186-91.

12. Altunas A. Hyponateiemia: Is it related to the seasons? J Med Biochem 2021; 40(4): 407-13.

13. Mannesse CK, Vondeling AM, van Marum RJ, van Solinge WW, Egberts TC, Jansen PA. Prevalence of hyponatremia on geriatric wards compared to other settings over four decades: a systematic review. Ageing Res Rev 2013; 12(1): 165-73.

14. Clark BA, Shannon RP, Rosa RM, Epstein FH. Increased susceptibility to thiazide-induced hyponatremia in the elderly. J Am Soc Nephrol 1994; 5(4): 1106-11. 
15. Shapiro DS, Sonnenblick M, Galperin I, Melkonyan L, Munter G. Severe hyponatraemia in elderly hospitalised patients: prevalence, aetiology and outcome. Intern Med J 2010; 40(8): 574-80.

16. Helderman JH, Vestal RE, Rowe JW, Tobin JD, Andres R, Robertson GL. The response of arginine vasopressin to intravenous ethanol and hypertonic saline in man: the impact of aging. J Gerontol 1978; 33(1): 39-47.

17. Liamis $G$, Milionis $H$, Elisaf $M$. A review of drug-induced hyponatremia. Am J Kidney Dis 2008; 52(1): 144-53.

18. Liamis G, Filippatos TD, Elisaf MS. Electrolyte disorders associated with the use of anticancer drugs. Eur J Pharmacol 2016; 777: 78-87.

19. Frenkel NJ, Vogt L, De Rooij SE, Trimpert C, Levi MM, Deen PM, et al. Thiazide-induced hyponatraemia is associated with increased water intake and impaired ureamediated water excretion at low plasma antidiuretic hormone and urine aquaporin-2. J Hypertens 2015; 33(3): 627-33.

20. Liamis G, Filippatos TD, Elisaf MS. Thiazide-associated hyponatremia in the elderly: what the clinician needs to know. J Geriatr Cardiol 2016; 13(2): 175-82.

21. Anpalahan M. Chronic idiopathic hyponatremia in older people due to syndrome of inappropriate antidiuretic hormone secretion (SIADH) possibly related to aging. J Am Geriatr Soc 2001; 49(6): 788-92.

22. Rao MY, Sudhir U, Anil Kumar T, Saravanan S, Mahesh E, Punith K. Hospital-based descriptive study of symptomatic hyponatremia in elderly patients. J Assoc Physicians India 2010; 58: 667-9.

23. Chatterjee N, Sengupta N, Das C, Chowdhuri AR, Basu AK, Pal SK. A descriptive study of hyponatremia in a tertiary care hospital of Eastern India. Indian J Endocrinol Metab 2012; 16(2): 288-91.

24. Babaliche P, Madnani S, Kamat S. Clinical profile of patients admitted with hiponatremia in the medical intensive care unit. Indian J Crit Care Med 2017; 21(12): 819-24.
25. Ishikawa Se, Saito T, Fukagawa A, Higashiyama M, Nakamura T, Kusaka I, et al. Close association of urinary excretion of aquaporin-2 with appropriate and inappropriate arginine vasopressin-dependent antidiuresis in hyponatremia in elderly subjects. J Clin Endocrinol Metab 2001; 86(4): 1665-71.

26. Whyte M, Down C, Miell J, Crook M. Lack of laboratory assessment of severe hyponatraemia is associated with detrimental clinical outcomes in hospitalised patients. Int J Clin Pract 2009; 63(10): 1451-5.

27. Funk GC, Lindner G, Druml W, Metnitz B, Schwarz C, Bauer $\mathrm{P}$, et al. Incidence and prognosis of dysnatremias present on ICU admission. Intensive Care Med 2010; 36(2): 304-11.

28. Sood N, Sharma KN, Himral P, Sharma T, Kapoor D. Clinical profile of patients with hyponatremia in a tertiary care hospital in the sub-Himalayan region. J Family Med Prim Care 2020; 9(2): 834-8.

29. Rahil Al, Khan FY. Clinical profile of hyponatraemia in adult patients admitted to Hamad General Hospital, Qatar: Experience with 53 Cases. J Clin Diag Res 2009; (3): 1419-25

30. Pillai KS, Trivedi TH, Moulick ND. Hyponatremia in ICU. J Assoc Physicians India 2018; 66(5): 48-52.

31. Krishnamurthy H, Srinivas K. »The Hyponatremia. "A real masquerader in emergency medicine. Int J Contemp Med Res 2015; 4: 515-9.

32. Liamis G, Filippatos TD, Elisaf MS. Correction of hypovolemia with crystalloid fluids: individualising infusion therapy. Postgrad Med 2015; 127(4): 405-12.

33. Spasovski G, Vanholder R, Allolio B, Annane D, Ball S, Bichet $D$, et al. Hyponatraemia Guideline Development Group. Clinical practice guideline on diagnosis and treatment of hyponatraemia. Nephrol Dial Transplant 2014; Suppl 2: i1-i39. 